\title{
Greenstone belts in the central Godthåbsfjord region, southern West Greenland
}

\author{
Julie A. Hollis, Jeroen A.M. van Gool, Agnete Steenfelt and Adam A. Garde
}

In 2004 the Geological Survey of Denmark and Greenland (GEUS) initiated a study of the origin and tectono-metamorphic evolution of greenstone belts and important regional structures in the central Godthåbsfjord region, southern West Greenland (Fig. 1; Hollis et al. 2004). Like other Archaean belts worldwide, these greenstone belts are locally host to gold mineralisation. Their complexity requires a combination of detailed geological mapping, geochemistry, petrographic work and geochronological studies to develop models of their geological setting, evolution and gold mineralisation.

\section{Regional geology}

The greenstone belts in the Godthåbsfjord region represent remnants of Archaean intrusive and extrusive mafic rocks, and minor chemical and clastic sediments. These were once thought to be dismembered parts of the same greenstone belt, but are now known to belong to unrelated groups of different ages, occurring within several distinct continental crustal terranes - the Færingehavn, Akia and Tre Brødre terranes (Fig. 1; e.g. Schiøtte et al. 1988). These terranes were amalgamated at 2950-2700 Ma (e.g. Friend \& Nutman 2005). The 3850-3300 Ma Færingehavn terrane largely comprises early Archaean tonalitic orthogneiss, granite, ultramafic and gabbroic rocks, together with rocks of inferred supracrustal origin, all of which are intruded by mafic Ameralik dykes. The 3200-2975 Ma Akia terrane comprises orthogneiss and greenstones. The 2826-2750 Ma Tre Brødre terrane, which is in tectonic contact with the Færingehavn terrane in many parts of the central Godthåbsfjord region, and also with the Akia terrane (Fig. 1), is dominated by late Archaean (c. 2825 $\mathrm{Ma})$ orthogneiss, but also includes metasedimentary and mafic volcanic rocks and gabbro-anorthosite. The boundary
Fig. 1. Overview map of the central Godthåbsfjord region - the focus of mapping and sampling in 2004 - and distribution of greenstone belts (dominantly comprised of amphibolite). 1, Bjørneøen greenstone belt; 2 , Qussuk greenstone belts; 3, Storø greenstone belt. Insets show distribution of major tectonostratigraphic terranes, and regional location of the mapping area. $\mathbf{Q}$, Qingaaq.

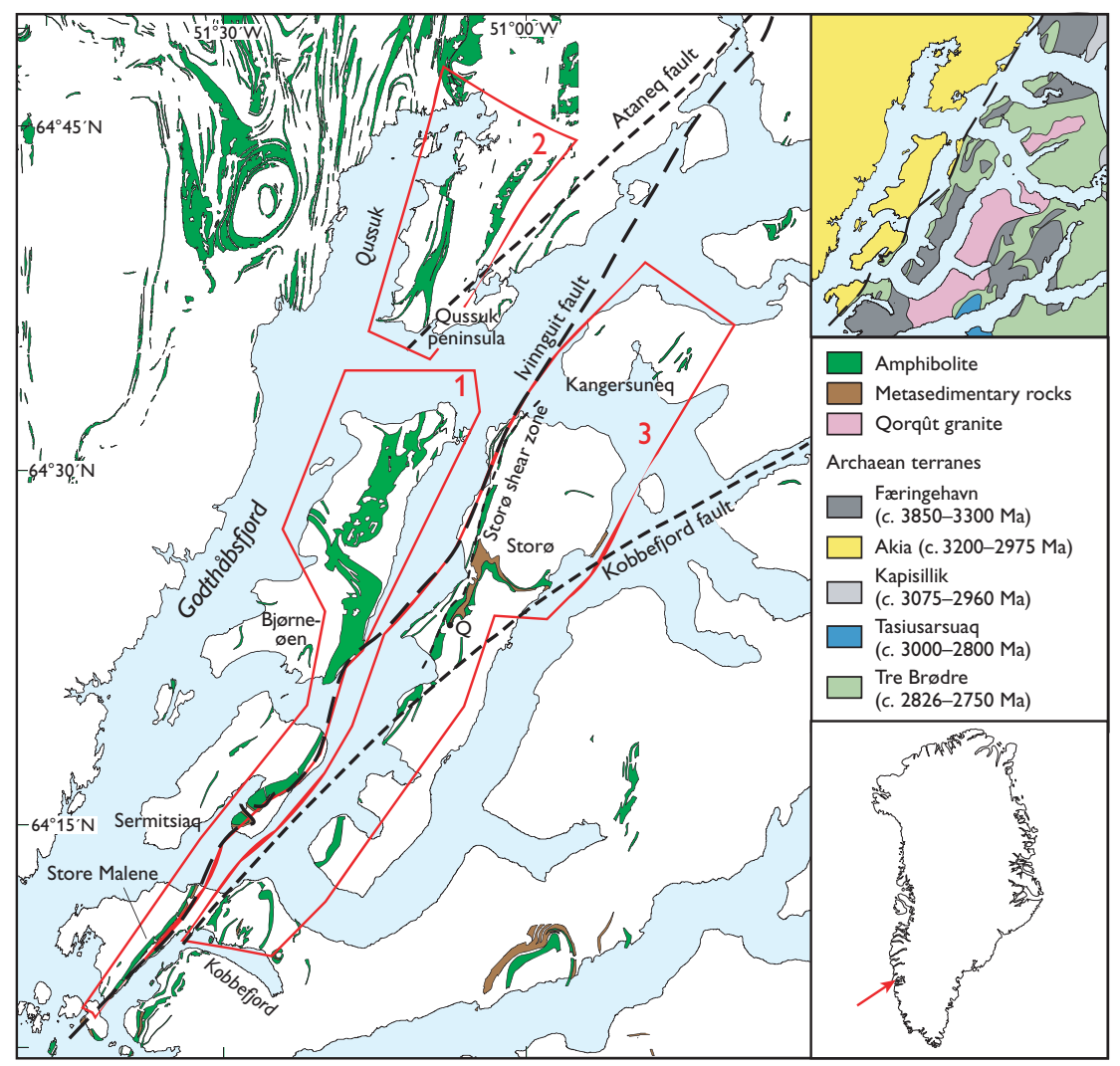




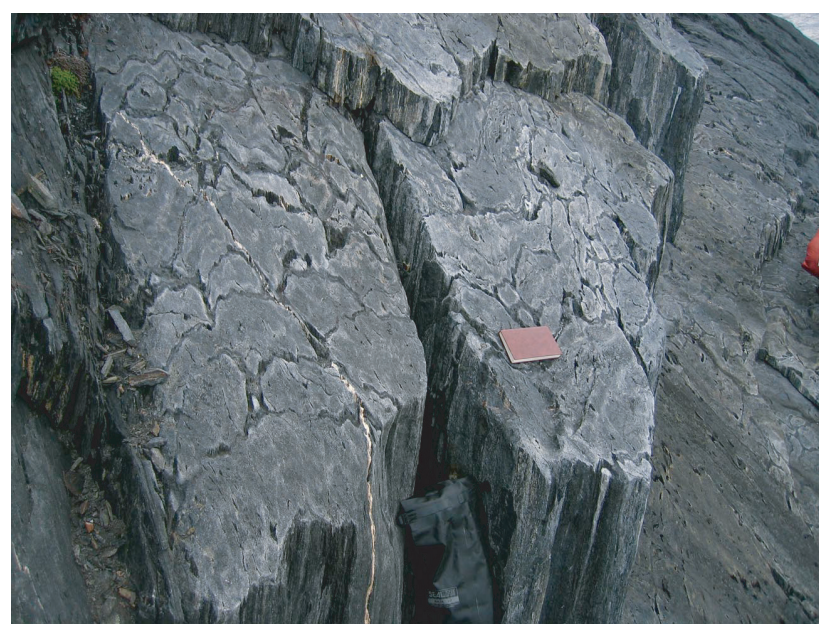

Fig. 2. Deformed pillow lavas on south-east Bjørneøen, looking east, showing eastward younging direction.

between the Tre Brødre and Akia terranes is the high-grade mylonitic Ivinnguit fault (c. 2720-2710 Ma; e.g. Friend et al. 1987), which can be traced continuously for tens of kilometres (Fig. 1). The emplacement of the Qôrqut sheeted granite complex (c. 2530 Ma; Fig. 1) in central Godthåbsfjord postdated regional terrane assembly. Post-Archaean events include emplacement of Proterozoic dolerite dykes (2400 $-2200 \mathrm{Ma}$ ) and regional-scale faulting, e.g. the NE-SWtrending Kobbefjord and Ataneq faults (Fig. 1).

\section{Greenstone belts: structure, lithology and mineralogy}

Three distinct NNE-SSW-trending greenstone belts can be recognised in the central Godthåbsfjord region: the Storø, Bjørneøen and Qussuk greenstone belts (Fig. 1). Based on cross-cutting relationships and existing geochronological data, these belts lie in the Akia (Qussuk and Bjørneøen belts) and the Tre Brødre (Storø belt) terranes (Fig. 1).

\section{The Bjørneøen greenstone belt}

The Bjørneøen greenstone belt (> $2975 \mathrm{Ma}$, Akia terrane) is a continuous NNE-SSW-trending belt which shows tight to isoclinal folding, large-scale, upright folding, NW-directed thrusting along NE-SW-striking high strain zones, and late brittle to semi-ductile reworking of ductile structures. The Ivinnguit fault forms a tectonic base to part of the Bjørneøen greenstone belt (Fig. 1).

The belt is dominated by mafic amphibolites, with lesser intermediate schist, metagabbro and ultramafic rocks, and minor garnet- and tourmaline-rich rocks of inferred sedimentary and volcanic origin. The mafic amphibolites are

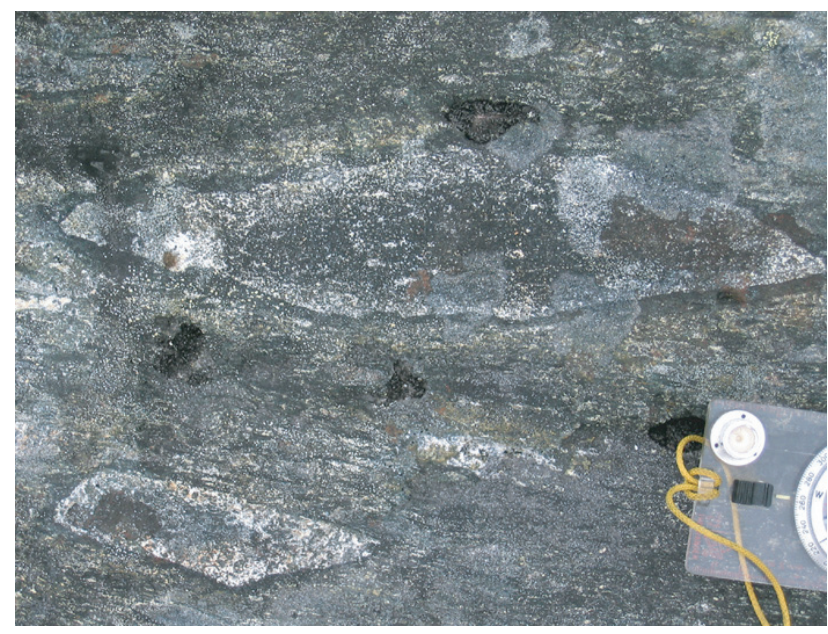

Fig. 3. Angular volcanic clasts in amphibolite of intermediate composition, Qussuk peninsula.

variably calc-silicate banded with rare pillow structures preserved in areas of low strain (Fig. 2). Schists of intermediate composition also preserve angular clasts of inferred volcanic origin in areas of low strain. Thin packages of layered metasedimentary and metavolcanic rocks are seen at Store Malene, Sermitsiaq and south-east Bjørneøen (Fig. 1) and commonly contain tourmaline-rich layers; in some cases they define refolded folds. They have been interpreted as stratabound syngenetic deposits, closely associated with the tungsten mineral scheelite (CaWSO 4 ; Appel \& Garde 1987). Laminated quartzofeldspathic rocks may represent tuffs. Relatively minor units of garnet-bearing quartzite and garnet-biotite schist \pm muscovite, zoisite, chlorite and tourmaline occur, along with anthophyllite-cordierite-bearing magnesian schists and cordierite-bearing quartzitic rocks. This belt reached only upper greenschist to lower amphibolite facies conditions.

\section{The Qussuk greenstone belts}

The Qussuk greenstone belts (> $2975 \mathrm{Ma}$, Akia terrane) may be contiguous with the Bjørneøen belt. They occur as NNE-SSW-trending, isoclinally folded and steeply dipping units of kilometre-thickness. Rock types present include intermediate and mafic amphibolites, with lesser amounts of metagabbro, ultramafic rocks and minor garnet- and tourmaline-rich rocks of inferred sedimentary and volcanic origin. The amphibolite units are dominated by rocks of intermediate composition. In areas of low strain these preserve decimetre-scale angular clasts inferred to be volcanic in origin (Fig. 3). These fragmental rocks commonly occur in association with laminated quartzofeldspathic rocks that may have been tuffs. Rare quartz-rich garnet and locally tourmaline- 
bearing rocks may be volcanogenic-exhalative or hydrothermal in origin, similar to the tourmaline-rich rocks from the Bjørneøen belt.

\section{The Storø greenstone belt}

The Storø greenstone belt is interpreted as part of the Tre Brødre terrane because of intrusive contacts with inferred late Archaean orthogneiss at the structural base of the belt on Storø. The outcrop of this belt on Storø - the focus of gold exploration in the region - is largely controlled by the 200-300 m wide Storø shear zone and associated kilometrescale folds (Fig. 4). The Storø shear zone runs parallel to the older Ivinnguit fault along the north-west coast of Storø, and has excised part of the belt along this section (Fig. 1). Outside the Storø shear zone, the belt preserves tight to isoclinal folds reflecting earlier deformation.

The Storø belt is dominated by mafic amphibolites with rare pillow structures, banded amphibolites, mica schists, sillimanite- and mica-bearing quartzites, thin iron formations, and lenses of ultramafic rocks. A gabbro-anorthosite body at the structural base of the belt forms the core of two large doubly plunging antiforms in the hanging wall of the Storø shear zone. North and south of Storø the belt thins and metasedimentary rocks are rare. Pelitic schists throughout the Storø belt preserve amphibolite facies mineral assemblages, which pre-date the Storø shear zone and include garnet, biotite, plagioclase, quartz \pm sillimanite \pm muscovite \pm cordierite \pm graphite \pm staurolite.

\section{Primary depositional environments and plate tectonic setting}

In the Bjørneøen belt the common occurrence of tourmaline (indicating boron-rich compositions) and scheelite in stratabound settings, together with the spatial association with pillow structures in mafic amphibolite, are consistent with a submarine exhalative setting with associated alteration via hot circulating fluids (cf. Appel \& Garde 1987). In the Qussuk belts tourmaline-rich quartzitic rocks may be indicative of a similar setting. Mafic amphibolites from the Qussuk and Bjørneøen belts preserve flat rare-earth element (REE) spectra consistent with an oceanic plateau environment. However, intermediate rocks from both belts show elevated light REE spectra, and some mafic amphibolites from the Bjørneøen belt show mixed signatures, suggestive of a possible island-arc environment. This indicates more than one important magmatic source for the Qussuk and Bjørneøen belts.

The gabbro-anorthosite body at the structural base of the Storø greenstone belt may be indicative of an oceanic, riftrelated setting, an interpretation supported by rare pillow structures in mafic amphibolites and the occurrence of ultramafic lenses that may represent former dykes. However, the inferred tuffite origin of intermediate amphibolite and the occurrence of quartzite units indicate a significant continental source. These observations fit with an island-arc proximal to a continent, or a change in environment during formation of this belt. Further geochemical analyses and geochronological constraints are required.

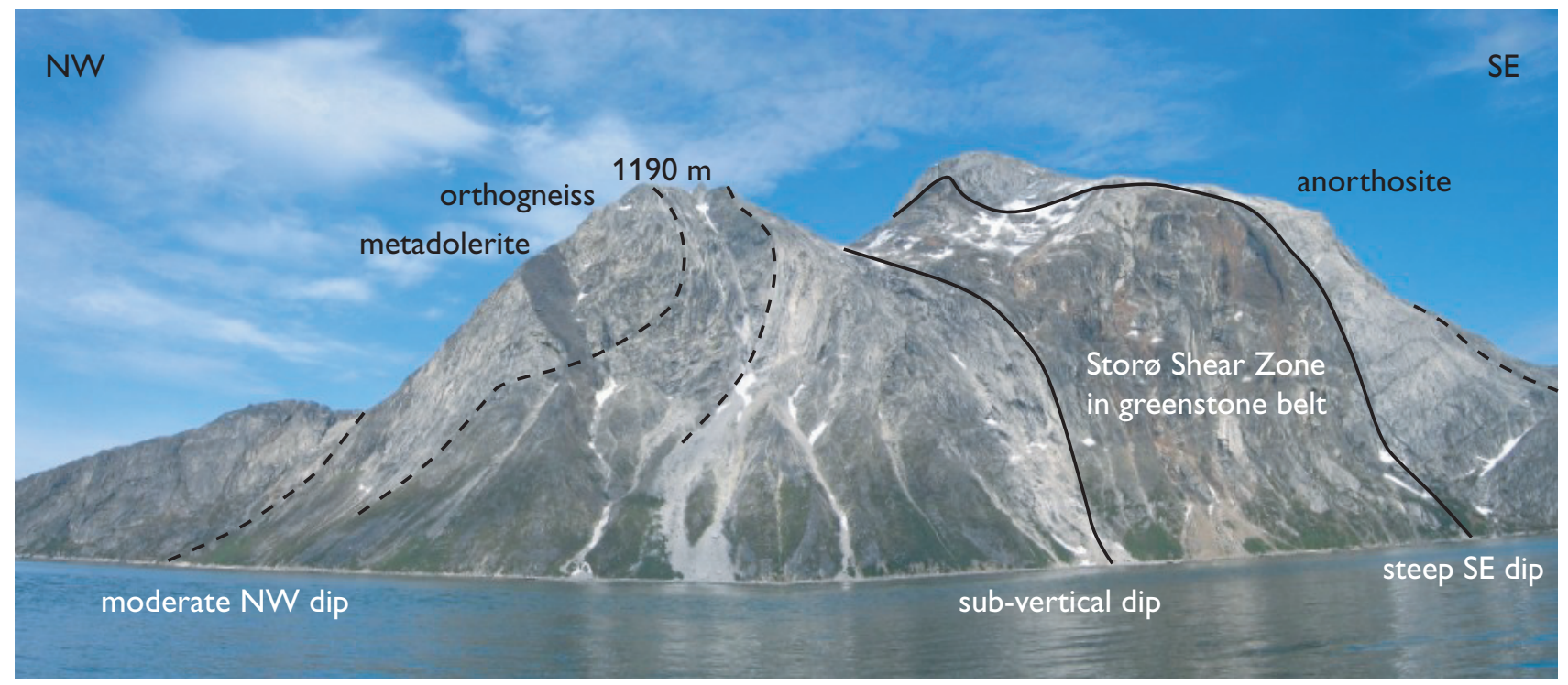

Fig. 4. East-closing synform in the footwall of the Storø shear zone, on the south-western slopes of Qingaaq mountain on Storø (see Fig. 1 for location). 


\section{Mineral occurrences and implications for mineral exploration}

Regional studies have identified a NNE-SSW-trending zone through central Godthåbsfjord with anomalous gold, and gold pathfinder elements (Steenfelt et al. 2003). This zone is parallel to the trace of the Ivinnguit fault. High gold values have been reported from mica schists and amphibolite on Storø (NunaMinerals A/S, licence number 2002/07; e.g. Appel et al. 2000), where exploration and prospecting activities continue.

Trace element data for rock, stream sediment and soil samples obtained in 2004 corroborate the high gold values previously found on Bjørneøen (Skyseth 1998; Smith 1998), but also identify previously unrecognised gold occurrences on the Qussuk peninsula. Here values of 1.4 and $2.3 \mathrm{ppm}$ Au were measured in samples of respectively an intermediate amphibolite and a tourmaline-bearing quartzitic rock of inferred hydrothermal origin. This may be indicative of a link between early hydrothermal processes (possibly in a submarine volcanic environment) and gold mineralisation.

Mapping in 2004 and geochemical analyses of samples from altered zones related to shear zones and faults (including the Ivinnguit and Ataneq faults) did not identify a relationship between these structures and anomalous gold values. In fact, field relationships point to mineralisation early in the tectono-metamorphic history. Geochemical results show gold occurrences in all three greenstone belts and - particularly in the case of the Qussuk belt - not necessarily related to shear zone or fault structures. The NNE-SSW-trending anomalous zone may simply be a reflection of the trend of greenstone belts in this region, rather than indicative of a relationship to NNE-SSW-trending structures, such as the Ivinnguit fault terrane boundary.

\section{Further work}

Further geochemical analyses of key major and trace elements are required to build on correlations and develop models for primary tectonic settings. Important issues include the determination of absolute timing constraints on regional structures, the deposition history of sedimentary and volcanic rocks, and the metamorphic history. Over 70 structurally constrained samples have been collected for this purpose. Further fieldwork is also required to investigate some of the important findings, and to extend the study to greenstone belts further afield in the Godthåbsfjord region.

\section{Acknowledgements}

This project was financially supported by the Bureau of Minerals and Petroleum, Nuuk, Greenland and undertaken in parallel with related GEUS projects.

\section{References}

Appel, P.W.U. \& Garde, A.A. 1987: Stratabound scheelite and stratiform tourmalinites in the Archaean Malene supracrustal rocks, southern West Greenland. Bulletin Grønlands Geologiske Undersøgelse 156, 26 pp.

Appel, P.W.U., Bliss, I.C., Coller, D.W., Grahl-Madsen, L. \& Pedersen, J.S. 2000: Recent Au discoveries in Archaean rocks of central West Greenland. Transactions of the Institution of Mining and Metallurgy (Sect. B: Appl. Earth Sci.) 109, B34-B41.

Friend, C.R.L. \& Nutman, A.P. 2005: New pieces to the Archaean terrane jigsaw puzzle in the Nuuk region, southern West Greenland: steps in transforming a simple insight into a complex regional tectonothermal model. Journal of the Geological Society (London) 162, 147-162.

Friend, C.R.L., Nutman, A.P. \& McGregor, V.R. 1987: Late-Archaean tectonics in the Færingehavn - Tre Brødre area, south of Buksefjorden, southern West Greenland. Journal of the Geological Society (London) 144, 369-376.

Hollis, J.A., van Gool, J.A.M., Steenfelt, A. \& Garde, A.A. 2004: Greenstone belts in the central Godthåbsfjord region, southern West Greenland: preliminary results from field work in 2004. Danmarks og Grønlands Geologiske Undersøgelse Rapport 2004/110, 110 pp. + 1 DVD

Schiøtte, L., Compston, W. \& Bridgwater, D. 1988: Late Archaean ages for the deposition of clastic sediments belonging to the Malene supracrustals, southern West Greenland: evidence from an ion probe U-Pb zircon study. Earth and Planetary Science Letters 87, 45-58.

Skyseth, T. 1998: Gold exploration on Storø 1997, South West Greenland, 25 pp. Unpublished report, NunaOil A/S, Nuuk, Greenland (in archives of Geological Survey of Denmark and Greenland, GEUS Report File 21601).

Smith, G.M. 1998: Report on the structure and geometry of the gold mineralization at Qingaq Storø, Nuukfjord, South West Greenland, 13 pp. Unpublished report, NunaOil A/S, Nuuk, Greenland (in archives of Geological Survey of Denmark and Greenland, GEUS Report File 21602).

Steenfelt, A., Moberg, E. \& Appel, P.W.U. 2003: Geochemical data indicative of mineral occurrences. In: Appel, P.W.U. et al.: Economic potential of the greenstone belts in the Nuuk area. General geology and evaluation of compiled geophysical, geochemical and ore geological data. Danmarks og Grønlands Geologiske Undersøgelse Rapport 2003/94, 58-66.

\footnotetext{
Authors' address

Geological Survey of Denmark and Greenland, Øster Voldgade 10, DK-1350 Copenhagen K, Denmark. E-mail: jho@geus.dk
} 